\title{
Johan Heyns as ekumeniese figuur
}

D Crafford

\section{ABSTRACT}

Johan Heyns as ecumenical figure

The role that Heyns played in ecumenical developments within the Dutch Reformed Church since 1986 is described. He played a leading role in breaking the ecumenical isolation of the Church. In his theology Heyns strongly emphasized the unity and the ecumenical calling of the church. His theological insights in this connection is described and evaluated. Special attention is given to what he said about the pluriformity of the church and about the diversity of confessions and the unity of the church. In conclusion his views on the practice of ecumenism is discussed.

\section{HEYNS SE EKUMENIESE BETROKKENHEID}

Johan Heyns was vanaf 1979 feitlik ononderbroke lid van die Sinodale Kommissie van die Algemene Sinode wat tegelyk ook die Ekumeniese Kommissie is. Vanaf 1986 tot 1990 was hy moderator en die voorsitter van die kommissie. In hierdie hoedanighede was hy direk betrokke by die ekumene in 'n opwindende tyd vir die Ned Geref Kerk. Dat daar 'n duidelike wending gekom het in die proses van isolasie van die Ned Geref Kerk sedert Cottesloe in 1960, is in 'n groot mate te danke aan die leierskap van Johan Heyns in die ASK en as moderator.

Die jaar waarin Heyns moderator geword het, 1986, kan juis as 'n duidelike draaipunt in die Ned Geref Kerk se ekumeniese verhoudinge gesien word. By die sinode van 1986 is die dokument Kerk en Samelewing aanvaar waarin die Ned Geref Kerk duidelik afskeid geneem het van die apartheidsformuleringe van die verlede. Dit is duidelik gestel dat die kerk se lidmaatskap oop is vir alle rasse. Vir hierdie koerswysiging is 'n duur prys betaal. In 1987 het die Afrikaanse Protestantse Kerk van die Ned Geref Kerk afgeskei omdat hulle nie met die formuleringe van Kerk en Samelewing saamgestem het nie. Vir Heyns as moderator, het dit veel pyn, drama en verguising beteken. Ten spyte van talle gesprekke kon die afskeiding nie gekeer word nie, en Heyns is in dié kringe as 'n verraaier van sy volk uitgekryt. Vir die konserwatiewe Afrikaners was die koerswysiging te groot, vir die leiers van die Ned Geref Kerk in Afrika en die Ned Geref Sendingkerk was dit nie betekenisvol genoeg nie. In die spanningsveld van die twee uiterstes het Heyns hom in 'n moeilike posisie bevind. Op 'n vergadering van die Federale Raad van Ned Geref Kerke in Maart 1988 waar gehoop is dat die spanninge met die dogterkerke verlig 
sou kon word, het die moderature van die Ned Geref Kerk in Afrika en die Ned Geref Sendingkerk uit die vergadering gestap. Heyns het alles in sy vermoë gedoen om die breukspul te heel en die lede terug te kry in die Raad. Van ware versoening was daar egter nie sprake nie.

Op voorstel van die Gereformeerde Ekumeniese Raad (=GER) wat in 1988 te Harare vergader het, is daar vanaf 6-8 Maart 1989 'n konsultasie van Ned Geref Kerke in Vereeniging byeengeroep. Die doel was om die spanninge binne die familie te bespreek en te probeer oplos. In 'n openingstoespraak het Heyns hom uitgespreek teen apartheid. Toe die afgevaardigdes van die dogterkerke daarop aandring dat apartheid as sonde verklaar moet word, het die Ned Geref Kerk geantwoord met 'n definisie van apartheid waarin die "ideologie van apartheid" omskryf en veroordeel is in soverre dit die menswaardigheid van ander rasse benadeel het. Met hierdie definisie was die jongkerke hoegenaamd nie tevrede nie en verhoudinge het verder versuur. Dit het aan die ander kant heftige reaksie uitgelok van die kant van dr Andries Treurnicht, die leier van die Konserwatiewe Party. Hierop het Heyns geantwoord: "Ons het by Vereeniging 'n prinsipiële uitspraak gemaak en nie die praktiese politiek van 'n party beoordeel nie"1. Ook hier moes Heyns dus 'n buffer vorm en selfs gemaal word tussen twee onversoenbare uiterstes in die samelewing van daardie jare.

In 1987 en 1988 het die Ned Geref Kerk twee ekumeniese byeenkomste gereël waarheen talle denominasies uitgenooi is. Meeste van die deelnemers het nie bande met die Suid-Afrikaanse Raad van Kerke gehad nie. Ook in hierdie inisiatiewe om die isolasie van die Ned Geref Kerk te deurbreek, het Heyns 'n leidende rol gespeel.

By die Algemene Sinode van 1990 het Heyns se termyn as moderator geëindig. Hy kon egter terugkyk op veel wat bereik is op die ekumeniese pad. 'n Nuwe uitgawe van Kerk en Samelewing is goedgekeur waarin apartheid in geen onduidelike taal verwerp is nie. 'n Ekumeniese beleid van die Ned Geref Kerk is aanvaar. Daar is besluit om bande aan te knoop met die Apostoliese Geloofsending; om waarnemerstatus by die Suid-Afrikaanse Raad van Kerke aan te vra en om 'n kerklike gesprek met die Rooms-Katolieke Kerk te begin ${ }^{2}$. In al hierdie positiewe ekumeniese ontwikkelinge het Heyns as moderator 'n belangrike rol gespeel.

Kort na die Sinode van 1990 het die Rustenburg beraad van kerke plaasgevind. Hier het prof W D Jonker die skuld van die Ned Geref Kerk oor apartheid openlik bely. Die belydenis is deur die vergadering aanvaar, maar die lede van die Ned Geref Kerk in Afrika en die Ned Geref Sendingkerk het bedenkinge gehad. Gelukkig kon die bedenkinge besweer word by die vergadering van die Federale Raad van Ned Geref Kerke in 1991. By dié geleentheid het die Raad eenparig die belydenis van die Ned Geref Kerk oor apartheid aanvaar. Die Ned Geref Sending- 
kerk wat reeds in 1990 uit die Federale Raad getree het, was nie teenwoordig nie. Nietemin het hierdie aanvaarding die lug gesuiwer en kon verskeie samesprekings oor eenheid tussen die moderature van die Ned Geref Kerke in die Republiek van Suid-Afrika daarna plaasvind. Aan al hierdie samesprekings het Heyns ook deel gehad en belangrike inisiatiewe gelewer.

Die wending in die Ned Geref Kerk se siening van apartheid het ook die deure na buitelandse kontakte oopgemaak. Ook in gesprekke met buitelandse kerke was Johan Heyns 'n leidende figuur. Hy het die vergaderings van die Gereformeerde Ekumeniese Raad in Zimbabwe (1988) en Athene (1992) bygewoon en die nuwe standpunte van die Ned Geref Kerk daar verduidelik. In 1991 is die Ned Geref Kerk uitgenooi om waarnemers te stuur na die Canberra - vergadering van die Wêreldraad van Kerke. Proff P C Potgieter en J A Heyns was die afgevaardigdes. In 'n artikel in Beeld van 13 Februarie 1991 beskryf Heyns die Wêreldraad as die belangrikste ekumeniese organisasie en beveel aan dat kerke deur so 'n ekumeniese ontmoeting verryk behoort te word. In 1991 het Emelio Castro, Algemene Sekretaris van die Wêreldraad van Kerke, Suid-Afrika besoek en ook samesprekings met die Moderatuur van die Ned Geref Kerk gehad. Na die sinode van 1990 het die Ned Geref Kerk ook met afgevaardigdes van talle buitelandse kerke samesprekings gevoer. By meeste van hierdie samesprekings was Johan Heyns ook teenwoordig.

Hierdie kort oorsig oor Heyns se betrokkenheid oor die afgelope dekade is genoeg om aan te toon dat hy nie net as ekumeniese figuur getipeer kan word nie, maar dat hy ook 'n reuse bydrae gelewer het in die proses om die Ned Geref Kerk uit sy ekumeniese isolasie te kry. Heyns het die veranderinge in die Ned Geref Kerk aangemoedig en bevorder maar hy wou dit ook op so 'n wyse laat geskied dat die meerderheid van die lidmate in die proses saamgeneem word. Dat hy nie die afskeiding van die Afrikaanse Protestantse Kerk kon keer nie, is nie sy skuld nie. Sy poging om sy eie mense met hom saam te neem het hom weer die kritiek van kerkleiers van die Ned Geref Kerk en Ned Geref Sendingkerk op die hals gehaal. Die gevolg was dat sy ekumeniese pad hom dikwels by albei partye onpopulêr gemaak het. Die geskiedenis sal egter uitwys dat Heyns op 'n verantwoordelike wyse'n reuse bydrae gelewer het om die Ned Geref Kerk uit die ekumeniese woestyn te lei en om tog uiteindelik tot beter verhoudinge met sy eie dogterkerke te kom.

Behalwe Heyns se praktiese betrokkenheid by die ekumene is dit ook nodig om te kyk na sy teologiese insigte oor die eenheid van die kerk en die ekumeniese roeping van die kerk. Hieraan wil ons vervolgens aandag gee. 
Die goue draad wat deur Heyns se teologie loop en die sleutel tot die verstaan daarvan, is die sentraliteit van die Koninkryk van God wat homself manifesteer in die koningsheerskappy van God in Christus en deur die Heilige Gees oor die kerk, maar ook in beginsel oor die ganse skepping. Met hierdie sleutel moet ook Heyns se verstaan van die eenheid van die kerk en die sendinggerigtheid van die kerk ontsluit word.

Beide sending en ekumene is opgeneem in God se plan met die wêreld. God wil sy koningsheerskappy oor die wêreld deels middellik deur die kerk en dus deur gelowige mense tot uitvoering bring 3 . Hulle moet die koninkryk proklameer en die tekens daarvan in die wêreld oprig. Die roeping tot beheersing en bewerking van die aarde beteken dat die kultuurskeppende handelinge van die mens ook in diens moet staan van die koninkryk. Die sleutelbegrip is dus gehoorsaamheid aan God se roeping en aan sy bedoelinge met die wêreld. God se bedoeling is die totale verlossing en bevryding van die wêreld. Vanweë die ongehoorsaamheid van sondige mense, tree hulle nie op in ooreenstemming met God se bedoeling nie. Daarom stuur God in Christus 'n gehoorsame Dienskneg na die wêreld. 'n Dienskneg wat volkome sy bedoelinge sou uitvoer. In Christus word nou 'n skare van gehoorsame diensknegte geroep. Dit is die volk van God wat as volk van gehoorsame diensknegte uit alle volke en rasse geroep is en in eenheid saamgebind is. Die kerk moet dus nou al iets vergestalt van die kosmies-eskatologiese belofte dat God alles in almal sal wees. Die koninkryksgestalte van die kerk konstitueer die eenheid van die kerk en wys vooruit na en werk vir die uiteindelike eenheid van die ganse skepping onder die koningsheerskappy van God. So word die eenheid van die kerk, vergestalt in sy ekumeniese handelinge, 'n teken en boodskap vir die wêreld'.

Hierdie een volk van gehoorsame diensknegte is egter ook gerig op die totale nood van die wêreld. Dit konstitueer die sendinggerigtheid van die kerk. Die kerk moet God se heil vir die wêreld bemiddel: "Die heil is die aankondiging van die koninkryk van God wat 'n werklikheid geword het"5. Jesus Christus is self die koninkryk omdat hy beide die heersende God en die gehoorsame mens verpersoonlik. Met die Christusverkondiging breek die koninkryk in die wêreld in oral waar sy heerskappy in gehoorsaamheid aanvaar word. Die kerk moet aan 'n sugtende wêreld die boodskap bring dat die verlossende Christus God se bedoeling vergestalt om alles wat in die hemel is en alles wat op die aarde is onder een hoof te verenig (Ef 1:10). So moet die kerk aan 'n lydende wêreld hoop bring wat 'n werklikheid word binne die raamwerk van die koninkryk.

Die kerk as koninkryksgemeenskap is dus tegelyk gehoorsaamheidsgemeenskap en heilsgemeenskap. As hy sy roeping uitvoer, word hy heilsbemidde- 
lende gemeenskap en eenheidsgemeenskap. Dit beteken dat die kerk draer word van heil en verlossing in 'n stukkende en sondige wêreld en 'n gestalte van eenheid vertoon in 'n verskeurde wêreld.

Vanuit bogenoemde denkraamwerk is beide ekumene en sending vir Heyns koninkrykswerk. In die sending is Christus bevrydend en triomferend aan die werk, want aan Hom is alle mag gegee in die hemel en op aarde. In die ekumene is Christus verenigend aan die werk, want Hy wil in I lom alles in die hemel en op die aarde verenig. Deur die sending en die ekumene kry die koninkryk van God sigbare gestalte in die wêreld.

Vanuit sy koninkryksteologie is daar 'n klank van optimisme en triomfantalisme in Heyns se teologie. Die koninkryk van God is onstuitbaar aan die kom in die wêreld. Die vraag is of hierdie oorwinningsteologie genoegsaam die realiteit van sonde, gebrokenheid en verskeurdheid in kerk en wêreld in ag neem. Iets meer van 'n teologia crucis sou dalk nodig wees om werklik antwoorde te bied aan mense se vrae oor die gebrokenheid wat ons daagliks beleef.

'n Interessante insig van Heyns is dat die sending die voortgesette vleeswording van die kerk in die wêreld is in navolging van die vleeswording van Christus. Die kerk moet deur sy lidmate in die wêreld vlees en bloed aanneem - die hande en voete van Christus word waardeur die nood en verlorenheid van die wêreld aangespreek kan word. Dit beteken dat in plaas van wêreldontvlugting die kerk geroepe is tot diensbaarheid aan die wêreld ${ }^{6}$.

DIE TEOLOGIESE BEGRONDING VAN DIE EKUMENE

Die ekumene word begrond in Heyns se trinitariese verstaan en fundering van die Kerk. Die Kerk se bestaan spruit voort uit die wil en ewige besluit van God. Dit is God se raadsbesluit dat daar één volk vir Hom versamel word uit al die nasies en dat daar één "gebou" vir Hom opgerig word in die wêreld (1 Kor 3:9). Die één God regeer oor één volk. Dit vorm die basis vir die leer van die eenheid van die kerk?

Christologies gesien, bestaan die kerk alleen in soverre dit "in Christus" bestaan. Die kerk vorm één liggaam met Christus as die hoof. Dit impliseer die verbondenheid van die lede aan mekaar. Dit wys ook heen na die instrumentele roeping van die lede, want deur hulle rig Christus Hom tot die wêreld. Deur sy liggaam wil Christus sy hoofskap, wat gestalte kry in sy knegskap, oor die ganse wêreld tot openbaring bring. Omdat daar één Hoof is, kan daar maar net één kerk wees. Pneumatologies is dit die inhabitasie van die Heilige Gees in die kerk wat die eenheid konstitueer. Die lede van die liggaam word saamgebind deur één Gees. Dit maak van die kerk 'n pneumatiese gemeenskap. Die trinitariese fundering van die kerk beteken dat die kerk wesenlik en substansieel één is en nooit iets anders kan wees nie. 
Ekumene beteken dus dat kerke in die hele bewoonde wêreld één is. Vir Heyns is dit nie net 'n geestelike en onsigbare eenheid nie. Die eenheid moet sigbaar word ter wille van die Here, ter wille van die kerk self en ter wille van die wêreld. Op die wyse waarop die eenheid vergestalt moet word, kom ons later weer terug.

Vanuit bogenoemde eenheid van oorsprong word verskillende gestaltes van eenheid afgelei. Daar is 'n "eenheid van roeping" wat alle gelowiges met mekaar deel; 'n eenheid van belydenis; van getuienis, gemeenskap en diens ${ }^{8}$. Dit alles dui daarop dat die eenheid belangrike implikasies het vir die lewe van die kerk elke dag. Vir Heyns is dit dus belangrik dat daar nie net 'n gegewe eenheid is nie, maar ook 'n gevraagde eenheid waaraan kerke hard sal moet werk. Hy wys daarop dat die eenheid so verinwendig en vergeestelik kan word dat ekumeniese samewerking van kerke onnodig word. Aan die ander kant kan dit so veruitwendig word dat organisatoriese en strukturele eenheid die enigste opsie is. Dit sou ekumeniese samewerking onmoontlik maak. Die eenheid kan ook gesien word as slegs 'n eskatologiese en toekomstige verwagting. Dit sou die stimulus vir samewerking van kerke wegneem.

Die gevraagde eenheid tussen kerke beteken dus dat die eenheid nie net geestelik en onsigbaar is nie; nie net organisatories en struktureel nie en ook nie net 'n toekomstige werklikheid nie. Dit moet hier en nou gestalte kry te midde van 'n verskeidenheid van konfessies en 'n veelheid van kerke. Dit bring ons by die vraag oor wat Heyns oor die veelheid en verskeidenheid van kerke sê.

Heyns gaan ook in op die vraag hoe die verskynsel van 'n veelheid van kerke beoordeel moet word. In die aanvaarding van pluriformiteit speel verskillende motiewe 'n rol. Die skeppingsmotief gaan uit van die standpunt dat soos daar 'n verskeidenheid in die natuur en in die volkerewêreld is, daar ook 'n verskeidenheid van kerke aanvaar moet word as die wil van God. Die ontplooiingsmotief gaan uit van die standpunt dat die openbaringswaarheid die potensiaal het om te ontwikkel tot veelvormigheid. Die waarheid is te groot om slegs op een manier geformuleer te word. Die verskeidenheid van kerke moet dus verwelkom word as medium vir die bekendmaking van die veelkleurige wysheid van God. Die antropologiese motief laat weer die klem val op die pluraliteit van menslike subjektiwiteit en menslike kontekste. Dit maak die pluriformiteit van kerke onvermydelik.

Heyns wys hierdie motiewe as 'n argument vir die noodsaaklike pluriformiteit van die kerk af. Trouens, hy beskou dit as in stryd met die Skrif en die reformatoriese konfessies. Maar dan gaan hy tog voort om die pluriformiteit van die kerk te verdedig op grond van 'n kultureel-etniese motief. Dit beteken dat 
onder verskillende volke met hulle eie tale, kulture, gewoontes en psigologiese instellinge 'n legitieme pluriformiteit van kerke kan ontstaan. Dit moet egter funksioneer as 'n verskeidenheid binne die één kerk.

Vir die aanvaarding van die kultuur-etniese motief stel Heyns drie voorwaardes:

(1) Dit moet 'n dinamies-vloeiende pluriformiteit wees en nie permanent staties nie. Om dié rede wil hy die volkereverskeidenheid sien as 'n voorsienigheidsordening van God eerder as 'n skeppingsordening. Dit beteken dat die etniese gestalte van die kerk met die tyd kan verander.

(2) Die pluriformiteit mag nie in 'n pluralisme verval nie. Dan word die verskeidenheid 'n innerlike verskeurdheid.

(3) Te midde van hulle verskeidenheid moet kerke steeds streef om uitdrukking te gee aan hulle eenheid. Dit kan geskied deur gesprek, gesamentlike aanbidding en samewerking op verskeie terreine ${ }^{9}$.

Ten spyte van bogenoemde kwalifisering van die kultuur-etniese motief, het Heyns nie gekom tot 'n skerp genoeg kritiek van die verskuiwing van 'n kultuur-etniese motief tot 'n rassistiese motief in die Nederduitse Gereformeerde Kerk nie. Die beleid van verskillende kerke vir verskillende volke het gelei tot 'n geslote blanke kerk waar nie-blankes de facto nie welkom was nie. Die kultuur-etniese motivering is deur die Nederduitse Gereformeerde Kerk verabsoluteer. Dit laat die vraag ontstaan of Heyns nie veel omsigtiger met die motief moes omgaan nie. Is dit geregverdig om etniese verskeidenheid selfs as 'n voorsienigheidsordening van God te sien of moet dit eerder as 'n praktiese realiteit gesien word waarin talle sondige motiewe ook 'n rol kan speel. Dit is waar dat 'n verskeidenheid van kontekste 'n verskeidenheid van bedieningspatrone tot gevolg sal hê. Is dit egter geregverdig om die kultuur-etniese konteks uit te sonder as enigste grond vir pluriforme bedieningspatrone? Dit kan maklik aanleiding gee tot ' $n$ eensydige beklemtoning van die aspek en het weinig gehelp om die misbruik van die kultuur-etniese motief in die lewe van die Nederduitse Gereformeerde Kerk hok te slaan.

\section{EENHEID EN WAARHEID: DIE VRAAG NA EKUMENE EN} BELYDENIS

Aan die hart van die ekumeniese probleem lê die feit van die groot verskeidenheid van konfessies waarmee kerke hulle teenoor mekaar afgrens. Die ekumeniese probleem kan dus nie opgelos word voordat daar nie 'n oplossing gevind word vir 
die konfessionele verskeidenheid nie.

Heyns gee ook aan hierdie vraagstuk aandag. Hy bring die konfessionele verskeidenheid in verband met die verduisterende uitwerking van die sonde. Hy gaan so ver om te sê dat ekumenisiteit dus die institutêre kerk se konkrete stryd teen die sonde is ${ }^{10}$. Die vraag is of dit nie te sterk gestel is nie. Daar is immers ook historiese, kontekstuele en kulturele oorsake vir 'n konfessionele pluraliteit. Om die waarheid van die evangelie relevant te maak vir' $n$ bepaalde tyd en 'n bepaalde konteks, is dit nodig dat dit elke keer weer nuut geformuleer moet word. Hier laat Heyns nie genoeg ruimte vir konfessionele diversiteit om te funksioneer binne die een liggaam van Christus nie. Die ekumene se doel is nie om konfessionele identiteit op te hef nie, maar om by te dra tot konfessionele vernuwing.

Heyns erken dat die leiding van die Heilige Gees nie gereserveer kan word vir een kerk nie ${ }^{11}$. Dit impliseer dat geen kerk alleen aanspraak kan maak op die volkome waarheid nie. Dit laat ruimte vir verskillende formuleringe van die waarheid. Hoe moet die ekumene nou reageer op konfessionele diversiteit? Een moontlikheid sou wees om belydenisse te reduseer tot 'n enkele basisformule wat deur verskillende kerke aanvaar kon word. Heyns wys hierdie uitweg van reduksie af, want daar behoort ruimte te wees vir verskillende wyses waarop die waarheid geformuleer kan word. Die eenheid van die waarheid is vir Heyns geleë in die eenheid van God wat Homself openbaar het in die een Christus en deur die een Gees. Die rykdom van die waarheid kan nie in enkelvoud beskryf word nie: "Oor die eenheid kan ons slegs in terme van veelheid spreek, maar dan gaan dit in die veelheid steeds om die eenheid"12. Indien die ekumene dus sou probeer om die waarheid tot 'n enkelvoud te reduseer kan dit volgens Heyns lei tot ekumeniese sektarisme. Dit beteken dat een aspek van die waarheid eensydig beklemtoon kan word. Enige vorm van seleksie hou dus gevare in. Die waarheid moet bely word as 'n organiese eenheid van leerstukke wat almal op mekaar aangewese is. Elke geloofstuk kry sy spesifieke inhoud eers in samehang met die geheel. Die eenheid van die kerk moet dus berus op die waarheid van alle geloofstukke. Heyns wys dus die ekumeniese kortpad van reduksie af. Die ekumene sal die moeisame pad van gesprek moet volg wat kan lei tot vernuwing, bekering en heiliging van die ganse kerklike lewe ${ }^{13}$.

Die kerk is in wese 'n belydende kerk, maar die vraag bly wat die inhoud van die belydenis moet wees. Vir Heyns is die inhoud van die belydenis die erkenning dat Jesus die Christus is, die Seun van die lewende God. Die probleem is dat hierdie kernbelydenis deur verskillende kerklike tradisies verder uitgebou is. Elke tradisie glo dat sy belydenis die beste uitdrukking is van die waarhede van die Skrif.

Volgens Heyns kan daar met betrekking tot die waarheidsvraag 'n absolutistiese en 'n relativistiese standpunt wees. Die absolutistiese standpunt sou wees 
dat die kerk se belydenis presies saamval met die grense van die waarheid. So 'n kerk sal moet leer dat sy beskouing beperk, begrens en perspektivies is. Hy het nie die hele waarheid in pag nie. Die relativistiese standpunt sien alles as relatief, onseker en voorlopig. Die waarheid kan dus eintlik nooit in 'n belydenis vasgelê word nie. So 'n kerk sal moet leer dat'n belydenis, in soverre as wat dit ooreenstem met die Skrif, tog 'n legitieme formulering van die waarheid is ${ }^{14}$.

Die eerste standpunt verabsoluteer die belydenis en die tweede negeer die belydenis. Volgens Heyns maak beide hierdie standpunte 'n egte ekumeniese ontmoeting onmoontlik. Die belydenis moet wel ernstig opgeneem word. 'n Kerk moet seker wees dat met die lig waaroor hy beskik sy belydenis wel in ooreenstemming met die Skrif is. Hy moet egter ook bereid wees om in gesprek met ander konfessies sy eie standpunte te toets aan die Skrif. So kan die ekumeniese gesprek help om die hermeneutiese vraagstuk op te los. Die wyse waarop die kerk deur die eeue en kerke op baie plekke die Skrif verstaan en uitgelê het moet in ag geneem word by enige uitleg van die Skrif. Dit beteken dat die belydenisse van verskillende tradisies bevrugtend op mekaar kan inwerk.

Met sy nadenke en standpunte oor Skrif, waarheid en belydenis het Heyns 'n waardevolle bydrae gelewer om die ekumeniese gesprek oor konfessies sinvol te mak sonder om in 'n oorskatting of onderskatting van die waarde van konfessies te verval. In die ekumeniese gesprek kan kerke mekaar inderdaad help om meer en meer te groei na die Skriftuurlike model van kerkwees en na 'n lewe van volkome gehoorsaamheid aan Christus ${ }^{15}$.

DIE PRAKTYK VAN DIE EKUMENE

Vanuit Heyns se kerkbegrip is die ekumene vir hom 'n onontwykbare roeping van die kerk: "Ter wille van die Here van die kerk, ter wille van die kerk, ter wille van die wêreld en ter wille van die koninkryk sal die ekumene beoefen moet word"16.

Heyns definieer die ekumene soos volg: "In die ekumene gaan dit om die één kerk van die één Here wat aan die één wêreld die één heil verkondig in Christus Jesus alleen"17. Elders word ekumene gesien as "alle pogings wat aangewend word tot bevordering, versterking en konsolidasie van die godsdienstige, kerklike en maatskaplike eenheid van alle Christene oor die hele wêreld heen"18.

In die definisies word te min klem gelê op die ekumene as roeping van die kerk, van elke gemeente en van alle gelowiges. Heyns sê baie min oor die praktiese uitvoering van die ekumene. Hy onderskei wel tussen verskillende grade van ekumeniese verhoudinge. Tussen kerke van gereformeerde belydenis behoort lidmaatskap onderling erken te word en mense oor en weer tot die sakramente toegelaat te word. Met kerke van algemeen Christelik-Protestantse belydenis sal die verhouding losser wees. Die aard van die verhouding word nie uitgespel nie. 
Met Rome word gesprek bepleit, maar as gevolg van die groot verskille in leer moet dit op indiwiduele vlak en dus skynbaar nie op amptelike vlak geskied nie. Oor ekumeniese betrekkinge met die Oosterse Ortodokse Kerk, Pinksterkerke, Charismatiese Kerke en Onafhanklike Swart Kerke word niks gesê nie.

Die omvang van ekumene word beskryf as die roeping van die hele kerk. Kerkraad, ring, sinode en algemene sinode moet daarby betrokke wees. Alle lidmate moet 'n ekumeniese gesindheid openbaar. Tog word nie uitgespel hoe ringe en kerkrade die ekumene kan beoefen nie. Terreine van samewerking word nie uitgespel nie en organe vir die beoefening daarvan word nie uitgespel nie.

'n Aantal leemtes in Heyns se ekumeniese beskouinge kan aangetoon word:

*Die ekumene as 'n beweging oor alle grense heen wat kerke van mekaar skei en as 'n proses waarby alle kerke betrokke moet wees, word nie genoegsaam in praktiese besonderhede uitgespel nie.

"Die ekumeniese beleid van die Ned Geref Kerk word nie krities genoeg betrag nie. Die eenheid binne die familie van Nederduitse Gereformeerde Kerke kon sterker beklemtoon gewees het. Die Federale Raad van Nederduitse Gereformeerde Kerke as ekumeniese liggaam verdien meer kritiese aandag.

*Heyns het weinig kennis geneem van ontwikkelinge binne die Wêreldraad van kerke. Van belangrike ekumeniese dokumente soos die "Baptism, Eucharist and Ministry"-dokument en die "Justice, Peace and Integrity of Creation"proses is nie genoegsaam kennis geneem nie.

*Heyns het hom nie eintlik uitgelaat oor dialoog met ander godsdienste nie. Trouens dit is 'n tekortkoming in sy dogmatiek dat ' $n$ theologia religionum so min daarin figureer.

\section{7}

\section{SAMEVATTING}

Ten spyte van die enkele leemtes het Heyns 'n reuse bydrae gelewer tot die bevordering van die kerk en die stimulering van die ekumene in Suid-Afrika. Hy pleit vurig vir die eenwording tussen die drie Afrikaanse kerke en sien dit as noodsaaklik en moontlik ${ }^{19}$. Hy neem deel aan talle gesprekke oor eenheid binne die familie van Ned Geref Kerke en werk mee aan 'n model waarvolgens die proses van eenwording bevorder kan word. Hy neem deel aan talle gesprekke met leiers van ander kerke en poog om sosiale vraagstukke gesamentlik met ander kerke aan te pak. 
Sy grootste bydrae is egter die teologiese uitbouing van die leerstuk van die eenheid van die kerk wat die onderbou vorm vir alle ekumeniese handelinge in die praktyk. Heyns het die teologiese grondslag deeglik gelê en oor moeilike vraagstukke duidelike leiding gegee. Hy laat dit oor aan ander om vanuit daardie teologiese beginsels aandag te gee aan die praktiese funksionering van die ekumene.

Dit lei geen twyfel nie dat Johan Heyns beide as gevolg van sy teologie en sy praktiese betrokkenheid by die ekumene in die geskiedenis bekend sal staan as 'n ekumeniese figuur.

\section{NOTAS:}

1 J A Heyns, "Vereeniging en 'apartheid", Die Kerkbode, 143/18, (19 Mei 1989), 6.

2 D Crafford en A G S Gous (redakteurs), Een Liggaam - baie lede, Pretoria 1993, 386v.

3 J A Heyns, "Die Kerk se ekumeniese roeping", in: P B van der Watt (red), Die Nederduitse Gereformeerde Kerk en sy ekumeniese verhoudinge, UP 1983, 75.

$4 \quad$ Heyns, $a w, 1983,77$.

5 J A Heyns, "Die sendinggerigtheid van die kerk", NGTT 30/4 (1989), 442.

$6 \quad$ Heyns, $a w, 1989,446$.

7 Heyns, $a w, 1983,77$.

8 J A Heyns, Die Kerk, Pretoria 1977, 116v.

9 Heyns, $a w, 1977,126 \mathrm{v}$.

10 Heyns, $a w, 1983,80$.

11 J A Heyns, "Gedagtes oor die Ekumene", Die Kerkbode, 12 Augustus 1964, 205.

12 Heyns, $a w, 1964$.

13 Heyns, $a w, 1964,208$.

14 Heyns, $a w,(5$ Augustus 1964), 180.

15 Heyns, $a w, 1983,84$.

16 Heyns, $a w, 1983,84$. 
17 Heyns, a w, 1964, 208.

18 Heyns, $a w, 1964,176$.

19 J A Heyns, "Eenwording van die Afrikaanse Kerke", Woord en Daad, 32(1992), 13-14. 